\title{
Effect of Service Quality Dimension and Marketing Mixed Dimension of Consumer Loyalty with Consumer Satisfaction as Mediation
}

\author{
Yohanes Andrianto ${ }^{1}$; Singgih Santoso ${ }^{2}$ \\ ${ }^{1}$ Student in Business Faculty, Master of Management Study Program, Duta Wacana Christian University, Indonesia \\ ${ }^{2}$ Lecturer in Business Faculty, Master of Management Study Program, Duta Wacana Christian University, Indonesia \\ http://dx.doi.org/10.18415/ijmmu.v6i5.1136
}

\begin{abstract}
The phenomenon of the emergence of many souvenir shops in the Purbalingga area of Central Java has resulted in increasingly strong business competition. In order to survive in the face of competition, business actors need to pay attention to important aspects in running their business. The author takes several aspects, namely the dimensions of service quality (physical evidence, reliability, responsiveness, assurance, empathy) and the dimensions of the marketing mix (products, prices, places, promotions) that can influence customer loyalty with customer satisfaction as mediation. The author makes the Original Nopia Shop as a research object because the shop is one of the souvenir shops that are quite old and famous in the Purbalingga area. The design of this study was a survey using a questionnaire distributed to 200 respondents of Original Nopia Store customers with a purposive random sampling method. Research variables were analyzed using Structural Equation Modeling (SEM) and obtained the following results: (1) Service quality significantly influences customer satisfaction, (2) Marketing Mix does not significantly influence customer satisfaction, (3) Consumer satisfaction has a significant effect on consumer loyalty, (4) consumer satisfaction does not mediate between the influence of service quality on consumer loyalty, (5) consumer satisfaction is able to mediate between the influence of marketing mix on consumer loyalty, (6) consumer satisfaction does not mediate between the influence of service quality and marketing mix simultaneously towards consumer loyalty.
\end{abstract}

Keywords: Service Quality; Marketing Mix; Customer Satisfaction; Customer Loyalty

\section{Introduction}

Indonesia Economic businesses in the current era is affecting the market competition is growing even stronger. The people determine their own goods and services that they want in accordance with the economic capabilities they have, so that business people are oriented towards the consumer market which means market conditions in the hands of consumers [1]. When businesses run a business, they must know what consumers want so that the business can run well and can dominate the market share. Many things can be done to increase consumer interest, one of which is by improving the quality of service and companies also need to pay attention to aspects of the marketing mix. 
Service quality and marketing mix are factors that influence customer satisfaction so that makes consumers become loyal. Consumers will be loyal and trust if a service is in accordance with the desired expectations [2] . If customer satisfaction is realized then loyalty to the store can also be realized. Also emphasized that store loyalty is an important factor in the success of retail trade and the store's ability to survive. Also in the current market era, loyalty to a retail store can be determined directly by the expectations of consumers of the products and services offered.

The phenomenon of the emergence of many souvenir shops applies also in the area of Purbalingga, Central Java. There is a large-scale gift shop or just the size of a kiosk. This needs to be considered by souvenirs business people to want to do research on their consumers. This needs to be done so that the management can make strategies in order to compete with other companies in order to gain market share.

One of the typical souvenirs of Purbalingga (Central Java) that is much in demand by buyers, is nopia bread or commonly called nopia. In Purbalingga, many stalls and souvenir shops sell nopia. But there is one of the oldest shops selling nopia, namely the Original Purbalingga Nopia Shop on Jalan AW Soemarmo No. 10 Purbalingga. Not only Nopia, but this shop sells a variety of typical Purbalingga foods which are usually used as souvenirs. According to Matthew Hirawan as a shop owner and nopia producer, he is the second generation to inherit the making of nopia. The first generation or predecessor to the nopia business was his father named Ting Lie Liang, who pioneered the business in early 1940. But over time the business process must follow the changing times to be more developed and able to survive.

Based on the description stated above, as the students of the Master of Management at Duta Wacana Christian University try to help develop an existing store. One of them is by conducting a study entitled "The Effect of Service Quality Dimensions and Marketing Mix Dimensions on Consumer Loyalty with Customer Satisfaction as Mediation ". Therefore this study will try to trace the effect of service quality and marketing mix on consumer satisfaction, giving rise to loyalty to consumers [3].

\section{Literature Review}

\subsection{Service Quality}

The definition of service quality is a measure of how well the level of service delivered is in accordance with customer expectations [4]. Service quality component is an aspect that can be evaluated by consumers to assess a service quality from a type of business [5]. There are five dimensions of SERVQUAL namely [6] :

\section{Physical Proof ( Tangible)}

Is the ability of a company to show its identity in physical form to other parties such as facilities available, equipment owned and the company's physical appearance.

2. Reliability

The company's ability to provide promising, reliable and accurate services.

3. Responsiveness

Willingness of the company to help customers and provide fast service.

4. Assurance

The ability of employees to make customers feel safe and trust the company. 


\section{Empathy}

The attention given by companies personally to consumers in order to better understand the desires of consumers.

\subsection{Marketing Mix}

Marketing mix is one of the marketing strategies that are used to provide information widely, introduce a product or service and stimulate consumers to create personal preferences for a product's image [7]. Planning a marketing mix is the main task in marketing management. A marketing manager must have careful planning and careful in order to meet the needs and desires of the market [8]. Many authors argue that understanding customer attitudes toward the 4P marketing mix is important [9]. Marketing Mix is a device that consists of product, price, place and promotion that can determine the success rate of marketing and all aimed to get a response to wants of the target market [10]. All elements of the marketing mix of product, price, place, and must work together to help design the best marketing strategies in the market [11]. The following is an explanation of each of the marketing mix dimensions:

\section{Product}

Product is anything that can be offered by producers to be noticed, sought, bought, used or consumed by the market as meeting the needs or desires of the relevant market [12]. Konsumen would like a quality product and has the features or performance of the best [13].

\section{2. $\quad$ Price}

The price is the fee charged for a product or service [14]. In economic theory that says there is a legal demand when prices rise, the number of products demanded by the market declines, while if the price drops, the number of products demanded by the market into the air -added [15].

\section{The place}

$\mathrm{T}$ four covers the activities of the company that made the product available to customers who become the target of target [16]. P endistribusian is a marketing activity to accelerate and facilitate the delivery of goods and services from producers to consumers [17].

\section{Promotion}

All information related to products must be disclosed transparently and openly so that there is no potential element of fraud and fraud in carrying out promotions [18] . P romosi a marketing activity by suppressing information that influence or persuade the target market that are willing to accept, purchase and loyalty to the products offered [19].

\subsection{Consumer Satisfaction}

Customer satisfaction is a construct that has emerged in various fields of study and has been the center of marketing concepts for decades [20] . K epuasan consumer is a happy feeling that is felt by a person when comparing performance or results in line with expectations or expectations of them [21].

\subsection{Consumer Loyalty}

Loyalty is when someone loyal consumers in the purchase of an object by repeatedly [22]. The notion that customer satisfaction leads to loyalty based on evidence that by growing customer satisfaction, customers tend to remain loyal to the laya provider nan [23]. Likewise, dissatisfied customers are more vulnerable to 
terminating business relationships so that customer satisfaction can be used to evaluate customer loyalty [24].

\section{Prior Research}

1. Rachmad (2009) conducted a study to measure the level of customer satisfaction and loyalty towards banking services in East Java. This research is categorized as a survey research with descriptive analysis method which takes a sample from the population and a questionnaire as the main data collection instrument. The population in this study were all Bank Mandiri customers in East Java [25].

2. Aryani and Rosinta (2010) examined that there was a significant and positive influence between KFC service quality variables on customer satisfaction among FISIP UI students. Other studies also have a significant and positive influence between the quality of KFC services on customer loyalty among FISIP UI students [26].

3. Gultom, Ginting and Sembiring (2014) conducted a study to determine the effect of the service marketing mix and service quality on student satisfaction in the management study program at the Faculty of Economics, University of Muhammadiyah, North Sumatra [27].

\section{Research Method}

Research conducted using a quantitative approach. In conducting this research, the authors use two kinds of data, namely primary data and secondary data. Primary data can be obtained by conducting surveys. The reason the authors use survey techniques is due to time and cost limitations. As for secondary data from previous studies that have been conducted. To apply the scientific method in practice in the field, a research design is needed in accordance with the conditions that occur in the field [28] .

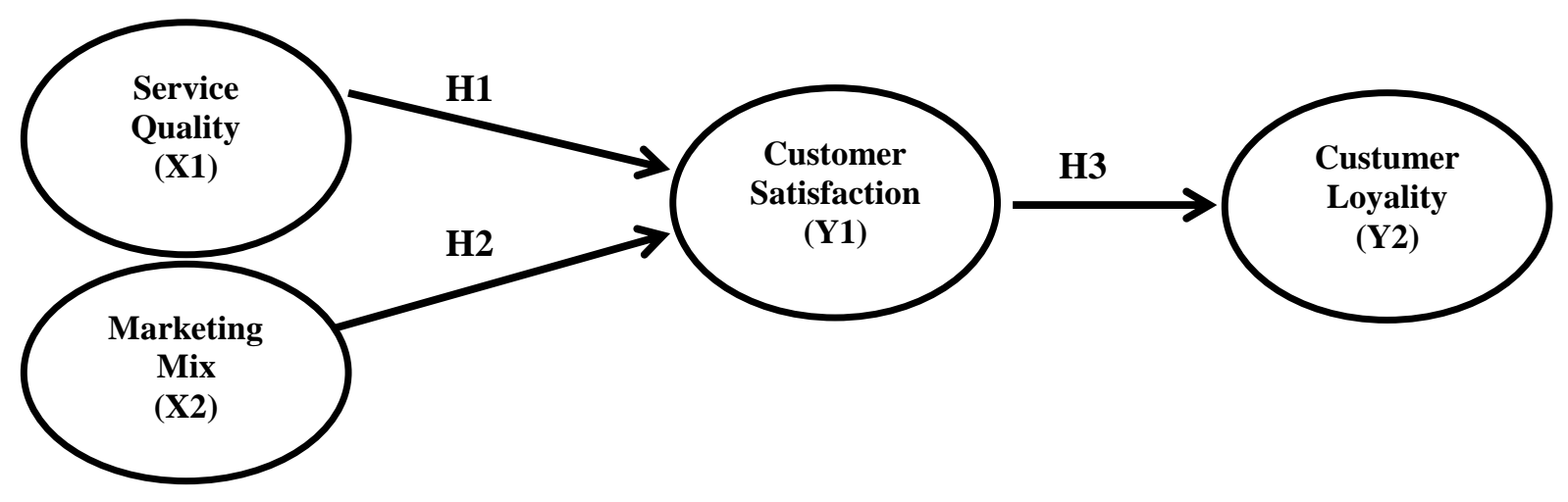

Figure 1. Research Model 


\subsection{Data Analysis Methods}

Equation Modeling Structure (SEM) is the most common statistical modeling technique and has been used extensively in behavioral science. Match test in SEM to evaluate the degree of compatibility or what is known as Goodness of Fit between data and models [29]. According to Hair et al. (1995) in (Hatane 2006) that the evaluation of GOF is carried out through several stages, namely: the suitability of the whole model, the suitability of the measurement model and the suitability of the structural model.

The following are GOF measures and compatibility levels that have been successfully combined by several authors in (Putro, Semuel and Brahmin 2014) [30]:

\section{Chi-square Statistics (x2)}

The smaller the better ( $p>0,05$ ). This tool is the most fundamental test tool for measuring overall fit, and is also very sensitive to the number of samples from research conducted. This results in the use of chi-square (x2) accurately if the study sample size is 100 to 200.

\section{RMSEA ( The Root Mean Square Error of Approximation )}

An index used to compensate for the chi-square (x2) statistic. If the value is smaller, the better and ( $\leq$ $0,08)$ is an index so that the model can be accepted.

\section{GFI ( Goodness of Fit Index )}

Is a suitability index that can calculate the weighted proportions of the variants in the matrix. The covariance of the sample described by the matrix is estimated population covariance. GFI values are between $0,00-1.00$; with a value $\geq 0.90$ is a good model (better fit).

\section{AGFI ( Adjusted Goodness of Fit)}

Is analogous to the coefficient of determination (R2) that exists in multiple regression analysis. This index can be adjusted to the degree of freedom available to test so that the model can be accepted. The recommended level of acceptance is AGFI $\geq 0,90$.

\section{CMIN / DF (The Minimum Sample Discrepancy Function)}

Usually reported by researchers as one indicator that measures the fit level of a model. CMIN / DF is $\chi^{2}$ divided by $\mathrm{df}$ so it is called $\chi^{2}$ relative. Relative $\chi^{2}$ value $\leq 2,0$ even $\leq 3.0$ is indicative of the model fit to the data.

\subsection{Hypothesis Testing}

Hypothesis test in this research is done by way of comparing the value of $\mathrm{P}$ by $5 \%$ or 0:05. If the $\mathrm{P}$ value is found to be smaller than 0.05 then the hypothesis that has been made in the research is supported (Santoso, 2015) [31].

\section{Results and Discussion}

\subsection{Test Validity}

Validity and reliability tests were conducted to determine whether each item of statement of service quality dimensions, dimensions of marketing mix, customer satisfaction and customer loyalty in the questionnaire was valid or not. Data processing from 200 respondents of Original Nopia Store 
customers was conducted using SEM method using the AMOS application. Analysis by SEM method is carried out to determine the correlation between the dimensions of service quality dimensions, the dimensions of the quality of the marketing mix, customer satisfaction and customer loyalty. An indicator can advance to the next stage or be declared valid if it has a loading factor greater than or equal to 0.5.

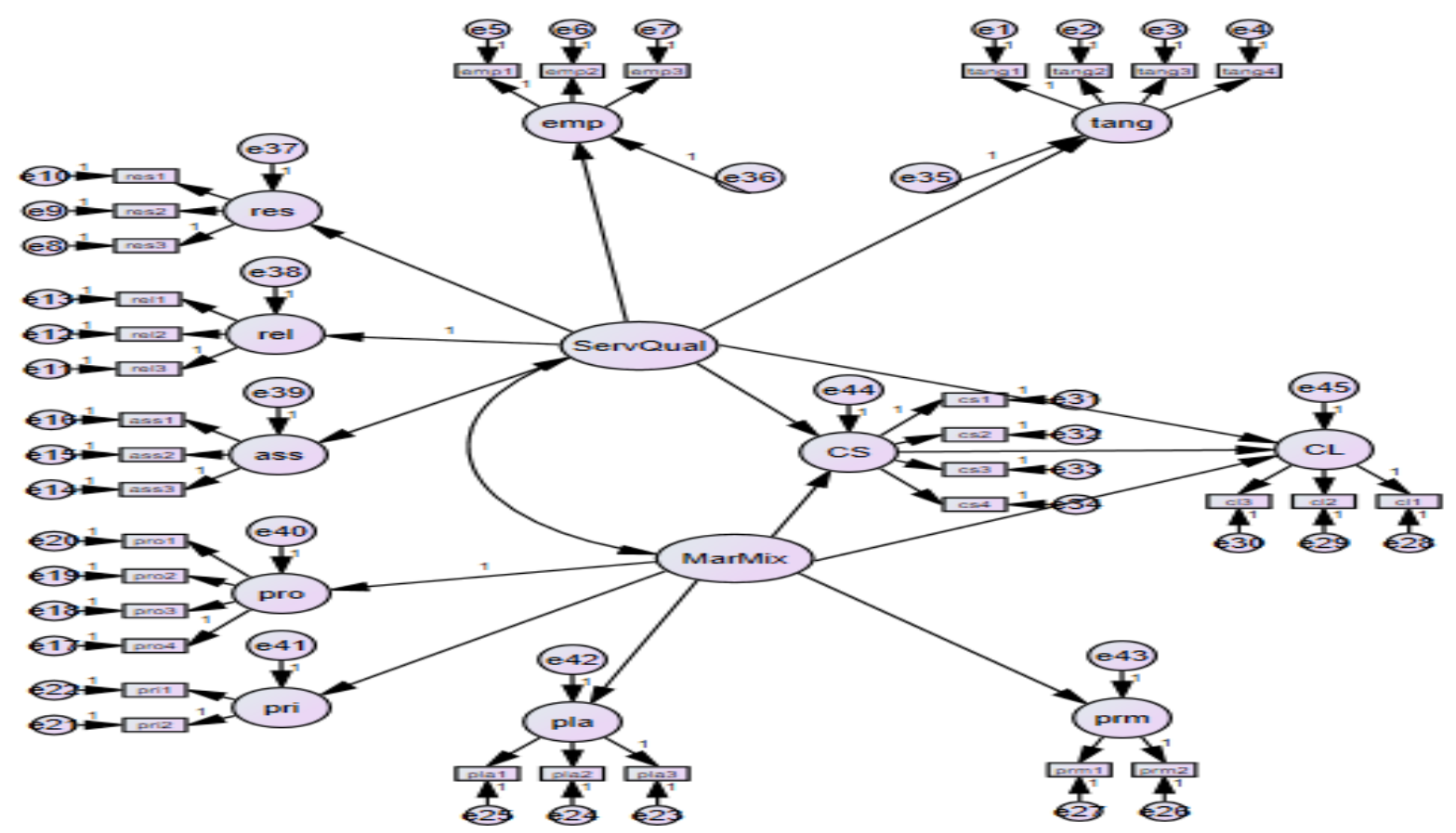

Data processing to 200 respondents using SEM method with AMOS applications such as the construct (path diagram) above gets the following results.

Table 4.4: Validity test

\begin{tabular}{|c|c|c|c|c|c|c|c|}
\hline \multicolumn{3}{|c|}{ Standardized Regression Weights } & \multirow{2}{*}{$\begin{array}{r}\text { Estimate } \\
0.859\end{array}$} & \multicolumn{3}{|c|}{ Standardized Regression Weights } & \multirow{2}{*}{$\begin{array}{r}\text { Estimate } \\
0.667\end{array}$} \\
\hline $\operatorname{tang1}$ & <--- & Tangible & & pro3 & $<--$ & pro & \\
\hline $\operatorname{tang} 2$ & $<---$ & Tangible & 0.618 & pro2 & $<---$ & pro & 0.735 \\
\hline $\operatorname{tang} 3$ & $<---$ & Tangible & 0799 & pro1 & $<---$ & pro & 0.731 \\
\hline $\operatorname{tang} 4$ & $<---$ & Tangible & 0.633 & pri2 & $<--$ & pri & 0.772 \\
\hline emp1 & $<---$ & Emphaty & 0.771 & pri1 & $<---$ & pri & 0835 \\
\hline emp2 & $<---$ & Emphaty & 0701 & pla3 & $<---$ & pla & 0769 \\
\hline emp3 & $<--$ & Emphaty & 0.766 & pla2 & $<---$ & pla & 0.796 \\
\hline res3 & $<---$ & responsive & 0822 & pla1 & $<--$ & pla & 0.756 \\
\hline res2 & $<--$ & responsive & 0770 & prm2 & $<--$ & prm & 0826 \\
\hline res 1 & $<---$ & responsive & 0728 & prm1 & $<--$ & prm & 0828 \\
\hline rel3 & $<---$ & Reliability & 0.734 & cl1 & $<--$ & CL & 0723 \\
\hline rel2 & $<--$ & Reliability & 0.634 & $\mathrm{cl} 2$ & $<---$ & CL & 0708 \\
\hline rel1 & $<--$ & Reliability & 0.733 & $\mathrm{cl} 3$ & $<--$ & $\mathrm{CL}$ & 0.738 \\
\hline ass 3 & $<--$ & Assurance & 0799 & $\operatorname{cs} 1$ & $<--$ & CS & 0.784 \\
\hline ass 2 & $<--$ & Assurance & 0.634 & $\operatorname{cs} 2$ & $<--$ & CS & 0769 \\
\hline ass1 & $<---$ & Assurance & 0.749 & $\operatorname{cs} 3$ & $<--$ & CS & 0.781 \\
\hline pro4 & $<---$ & product & 0814 & $\operatorname{cs} 4$ & $<--$ & $\mathrm{CS}$ & 0.631 \\
\hline
\end{tabular}


Based on the research indicators, the results obtained for each variable have a value above 0.5 . by Therefore, this study can be immediately resumed without discarding invalid variable.

\subsection{Results Goodness - of - Fit Criteria}

There are several indexes used as indicators to evaluate the Goodness-of-Fit criteria with the SEM method. The following is the result of calculating the Goodness-of-Fit criteria of a model that has been processed using index modification.

Table 4.1:Goodness of Fit Model Results

\begin{tabular}{lccl}
\hline \multicolumn{1}{c}{ Criteria } & Critical Value & Index & Information \\
\hline CMIN / DF & $\leq 2.00$ & 1,939 & Well \\
GFI & $\geq 0.90$ & 0.788 & Marginal \\
AGFI & $\geq 0.80$ & 0.741 & Marginal \\
TLI & $\geq 0.90$ & 0.902 & Well \\
CFI & $\geq 0.90$ & 0.914 & Well \\
RMSEA & $\leq 0.80$ & 0.069 & Well \\
\hline
\end{tabular}

Goodness-of-fit model test results using the AMOS application showed CMIN / DF results of $1,939 \leq 2.00$, GFI value of $0.788 \leq 0.90$, AGFI value of $0.741 \leq 0.80$, TLI value of $0.902 \geq 0.90$, CFI value of $0.914 \geq 0.90$ and RMSEA value of $0.069 \leq 0.08$. By looking at the results of the test, it can be concluded that the construct of this study can be accepted because it has met the indicator criteria for goodness-of- it .

\subsection{Hypothesis Test Results}

The way to test hypothesis one (H1), hypothesis two (H2) and hypothesis three (H3) in this study is done by a method of comparing the value of Probability $(\mathrm{P})$ with 0.05 . If the probability value is smaller than 0.05 , the hypothesis in this study is supported by its truth, whereas if the probability value is greater than 0.05 , the hypothesis in this study is not supported by the truth.

Table 4.2:Probability Value Between Variables

Information

Quality of Customer Satisfaction Services

Consumer Satisfaction Marketing Mix

Consumer Satisfaction Consumer Loyalty
Probability

0.013

0.079

0.039

With a look at the table above, it can be in take the conclusion that:

1. The relationship between service quality variables and customer satisfaction has a probability value of 0.013 or smaller than 0.05 so that the hypothesis one (H1) results are significant, namely service quality affects customer satisfaction.

The results of this study stated that hypothesis one (H1) was accepted. 
2. The relationship between marketing mix variables and customer satisfaction has a probability value of 0.079 or greater than 0.05 so that the hypothesis two $(\mathrm{H} 2)$ results are not significant, ie the marketing mix does not affect consumer satisfaction.

The results of this study stated that hypothesis two (H2) was rejected.

3. The relationship between variables of customer satisfaction and customer loyalty is 0.039 or smaller than 0.05 so that the hypothesis three (H3) results are significant, namely customer satisfaction affects consumer loyalty.

The results of this study stated that hypothesis three (H3) was accepted .

The hypothesis regarding the mediating variable is different from the previous variable, which is:

1. Hypothesis four (H4), namely consumer satisfaction mediating the quality of service to consumer loyalty can be calculated by looking at the value of direct effects and indirect effects from the results of statistical processing SEM. If the value of direct effects of service quality coupled with the value of direct effects of customer satisfaction results is greater than indirect effects of consumer loyalty, then the hypothesis is declared acceptable. Conversely, if the value of direct effects of service quality coupled with the value of direct effects of consumer satisfaction are smaller than indirect effects of consumer loyalty, then the hypothesis is declared not accepted.

2. Hypothesis four (H5), namely consumer satisfaction mediating the marketing mix of consumer loyalty can be calculated by looking at the value of direct effects and indirect effects from the results of SEM statistical processing. If the value of the direct effects of the marketing mix is added to the value of the direct effects of consumer satisfaction the results are greater than the indirect effects of consumer loyalty, then the hypothesis can be accepted. Conversely, if the value of the direct effects of the marketing mix is added to the value of the direct effects of consumer satisfaction the results are smaller than the indirect effects of consumer loyalty, then the hypothesis is not accepted.

3. Hypothesis four (H6), namely consumer satisfaction mediating service quality and marketing mix simultaneously to consumer loyalty can be calculated by looking at the value of direct effects and indirect effects from the results of statistical processing SEM. If the value of direct effects of service quality is added to the value of direct effects of the marketing mix coupled with the value of direct effects of consumer satisfaction the results are greater than indirect effects of consumer loyalty, then the hypothesis is declared acceptable. Conversely, if the value of direct effects of service quality coupled with the value of direct effects of the marketing mix coupled with the value of direct effects of consumer satisfaction are smaller than indirect effects of consumer loyalty, then the hypothesis is declared unacceptable. 
The results of data processing with SEM method using the AMOS application, the results obtained are the value of direct effects and indirect effects as the following table :

Table 4.7:The value of direct effects and indirect effects

\begin{tabular}{crr}
\hline Information & Direct Effects & Indirect Effects \\
\hline Quality of Customer Satisfaction Services & 2,956 & 0,000 \\
Consumer Satisfaction Marketing Mix & $-1,939$ & 0,000 \\
Consumer Satisfaction Consumer Loyalty & 5,067 & 0,000 \\
Quality of Customer Loyalty Services & 0,000 & $-14,115$ \\
Consumer Loyalty Marketing Mix & 0,000 & 9,766 \\
\hline
\end{tabular}

By looking at the table of direct effects and indirect effects values above, we can draw the conclusion that:

1. Hypothesis four (H4): value of direct effects of service quality on customer satisfaction $(2,956)+$ value of direct effects of customer satisfaction on loyalty $(5,067)=8,023>-14,115$ value of indirect effects of service quality on customer satisfaction.

It can be concluded that 8023 direct effects $>-14,115$ indirect effect, so that the variable of customer satisfaction does not mediate the variable quality of service to the variable of customer loyalty.

The results of this study stated that hypothesis four $(\mathbf{H 4})$ was rejected.

2. Hypothesis four (H5): the value of the direct effects of the marketing mix on consumer satisfaction $(-1,939)+$ the value of the direct effects of customer satisfaction on loyalty $(5,067)=3,128$ $<9,766$ values of the indirect effects of the marketing mix on consumer satisfaction.

It can be concluded that 3,128 direct effects $<9,766$ indirect effects, so that the consumer satisfaction variable mediates the marketing mix variable to the customer loyalty variable.

The results of this study stated that hypothesis five (H5) was accepted .

3. Hypothesis four (H6): value of direct effects on service quality on customer satisfaction $(2,956)+$ value of direct effects of marketing mix on customer satisfaction $(-1,939)+$ value of direct effects of customer satisfaction on loyalty $(5,067)=6,084$

Value of indirect effects service quality on customer satisfaction $-14,115+$ value of indirect effects marketing mix on customer satisfaction 9,766 $=-4,349$

It can be concluded that 6,084 direct effects $>-4,439$ indirect effects, so that the consumer satisfaction variable does not mediate the service quality variable and the marketing mix variable simultaneously against the consumer loyalty variable.

The results of this study stated that hypothesis six (H6) was rejected . 


\section{Conclusion}

Statistical test results using AMOS with the Structural Equation Modeling (SEM) method, the following data are obtained :

a. Service quality (physical evidence, empathy, responsiveness, reliability and guarantee) significantly influence consumer satisfaction,

b. Marketing Mix (product, price, place and promotion) does not significantly influence consumer satisfaction,

c. Consumer satisfaction has a significant effect on customer loyalty,

d. Consumer satisfaction does not mediate between the influence of service quality on consumer loyalty,

e. Consumer satisfaction is able to mediate between the influence of the marketing mix on consumer loyalty,

f. Consumer satisfaction does not mediate between the influence of service quality and marketing mix simultaneously on consumer loyalty.

\section{Suggestions}

1. For the Nurb Original Purbalingga Store company

The influence of the strategy regarding the determination of the marketing mix must be further enhanced, because it is proven that the marketing mix does not significantly influence consumer satisfaction. Companies must also pay more attention to factors other than service quality and marketing mix that can cause loyal or unfaithful consumers.

2. For further researchers

a. The area where further research is conducted is expected to be even broader and not just one research object,

b. The number of research respondents was further increased so that the expected results were more accurate.

c. Literature review in further research is expected from more updated sources since the holding of this study and does not take sources for too long.

\section{References}

1. Ruusen, F. B., dkk. (2014). Kualitas pelayanan, promosi dan after sales service pengaruhnya terhadap kepuasan konsumen sepeda motor honda pt. nusantara surya sakti di amurang. Jurnal EMBA. 2 (3), 1603-1613.

2. Wijaya, P. S. M. (2008). Pengaruh citra merek terhadap loyalitas konsumen starbucks coffe di yogyakarta. Jurnal Riset Manajemen \& Bisnis. 3(2), 158-176. 
3. Mulyono, B. H, dkk. (2007). Analisis pengaruh kualitas produk dan kualitas layanan terhadap kepuasan konsumen (studi kasus pada perumahan puri mediterania semarang). Jurnal Studi Manajemen \& Organisasi. 4 (2). 32-44.

4. Subagiyo, R. \& Adlan, M. A. (2017). Pengaruh service quality, marketing mix dan kepuasan mahasiswa terhadap customer loyalty. Jurnal Ekonomi Modernisasi. 13 (1), 1-15.

5. McDougall, G. H.G, \& Levesque, T. (2000). Customer satisfaction with service : Putting percieved value into the equation. Journal of Service Marketing. 14(5), 392-410.

6. Parasuraman, A., Valerie Zeithaml, and L.Berry. (1988). Servqual: Multiple item scale for measuring consumer perceptions of service quality. Journal of Retailing, 64 (15), 12-36.

7. Selang, C. A.D. (2013). Bauran pemasaran (marketing mix) pengaruhnya terhadap loyalitas konsumen pada fresh mart bahu mall manado. Jurnal EMBA. 1 (3), 71-80.

8. Shahhosseini, A. (2011). Marketing Mix Practices in the Cultural Industry". International Journal of Business and Management. 6(8), 22-36.

9. Purnomo S. H, Lee Y. H., \& Soekartawi. (2010). Why is understanding customer attitude toward 4Ps marketing mix important? The case of the livestock input industry in Indonesia. Journal of Development and Agricultural Economics. 2(4), 107-114.

10.Kotler, P. \& Keller. (2007). Manajemen pemasaran: Analisis, perencanaan, implementasi dan pengendalian. Edisi pertama. Jakarta: Prentice Hall, Salemba Empat.

11. Shahhosseini, A. (2011). Marketing mix practices in the cultural industry. International Journal of Business and Management. 6 (8), 13-25.

12.Ulus, A. A. (2013). bauran pemasaran pengaruhnya terhadap keputusan pembelian mobil daihatsu pada pt. astra internasional manado. Jurnal EMBA. 1(4), 1134-1144.

13.Wijaya, P.S.M. \& Suradal, D. S. (2009). "Pengaruh atribut produk, atribut layanan dan atribut pembelian terhadap kepuasan konsumen BEE's family resto di galeria mall yogyakarta". Jurnal Riset Manajemen \& Bisnis. 4(2), 89-102.

14. Kotler dan Amstrong. (2010). Prinsip-prinsip pemasaran, Jilid 1 \& 2, Edisi kedua belas. Jakarta: Erlangga.

15. Marlina, E. \& Ruhiat, D. (2018). Penerapan sub pokok fungsi pada matematika ekonomi terhadap fungsi permintaan dan fungsi penawaran. Jurnal Ilmiah Akuntansi. 9(2), 90-96.

16.Kotler, P. dan Susanto, A.B. (2008). Manajemen pemasaran di indonesia. Jakarta: Salemba Empat dan Pearson Education Asia Pte.Ltd.

17.Tjiptono, F. (2008). Strategi Pemasaran. Edisi Ketiga. Yogyakarta: Andi Ofset.

18.Dwiyananda, O.M. (2015), Pengaruh produk, harga, tempat, promosi ritel modern terhadap keberlangsungan usaha ritel tradisional di gresik. JESTT. 2 (9), 55-66.

19.Tjiptono, F., (2008). Strategi pemasaran. edisi ketiga. Penerbit ANDI. Yogyakarta. 
20.Ganiyu, R. A. (2017). "Customer satisfaction and loyalty: a study of interrelationships and effects in nigerian domestic airline industry". Oradea Journal Of Business And Economics, 1 (1).

21.Kotler,P dan Keller, K.L. (2016). Marketing management, $15^{\text {th }}$ edition, USA: Pearson Pretice Hall Inc, New Jersey.

22.Kumalaningrum, F., dkk. (2016), "Analisis pengaruh kualitas pelayanan terhadap loyalitas konsumen dengan kepuasan konsumen sebagai variabel moderasi (studi pada konsumen cs kopi tubruk surakarta)".Jurnal Ekonomi dan Kewirausahaan. 16 (2), 226 - 233.

23.Eriksson, K, Vaghult, A.L. (2000). Customer retention, purchasing behaviour and relationship substance in professional services. Industrial Marketing Management. 29(4), 363-372.

24.Andreas, A. (2010). Verifying alternative measures of the service - quality construct : Consistenciesand contradictions. Journal of Marketing Management. 26 (6), 570-587.

25.Hidayat, R. (2009). Pengaruh kualitas pelayanan,kualitas produk dan nilai nasabah terhadap kepuasan dan loyalitas nasabah bank mandiri. Jurnal Manajemen dan Kewirausahaan. 11(1), 59-72.

26. Aryani, D. dan Rosinta, F. (2010). Pengaruh kualitas layanan terhadap kepuasan pelanggann dalam membentuk loyalitas pelanggan (studi pada mahasiswa sarjana reguler dan diploma fisip ui), bisnis \& birokrasi. Jurnal Ilmu Administrasi dan Organisasi. 17(2), 114-126.

27.Gultom, D.K., Ginting, P. \& Sembiring, B.K.F. (2014). Pengaruh bauran pemasaran jasa dan kualitas pelayanan terhadap kepuasan mahasiswa program studi manajemen fakultas ekonomi universitas muhammadiyah sumatera utara. Jurnal Manajemen \& Bisnis. 14(1), 1-14.

28. Aryani, D. \& Rosinta, F. (2010). Pengaruh kualitas layanan terhadap kepuasan pelanggann dalam membentuk loyalitas pelanggan (studi pada mahasiswa sarjana reguler dan diploma fisip ui), bisnis \& birokrasi. Jurnal Ilmu Administrasi dan Organisasi. 17(2), 114-126.

29.Semuel, Hatane. (2006). Ekspektasi pelanggan dan aplikasi bauran pemasaran terhadap loyalitas toko moderen dengan kepuasan pelanggan sebagai intervening (studi kasus pada hypermarket carrefour di surabaya). 1(2), 53-64.

30.Putro, S.W., Semuel, H., Brahmana, \& Ritzky, K.M.R. (2014). Pengaruh kualitas layanan dan kualitas produk terhadap kepuasan pelanggan dan loyalitas konsumen restoran happy garden surabaya. Jurnal Manajemen Pemasaran. 2(1), 1-9.

Santoso, S. (2015). Amos 22 untuk Structural Equation Modeling. Jakarta : PT Elex Media Komputindo

\section{Copyrights}

Copyright for this article is retained by the author(s), with first publication rights granted to the journal.

This is an open-access article distributed under the terms and conditions of the Creative Commons Attribution license (http://creativecommons.org/licenses/by/4.0/). 